\title{
The Principle of Mutual Trust Versus the Child's Right to be Heard
}

\section{Some Observations on the Aguirre Zarraga Case}

\begin{abstract}
KatAlin RaFFAI*
Abstract. This central topic for this article is a CJEU decision that allows for the study of the application of the principle of mutual trust and a child's right to be heard in the enforcement of a decision ordering the return of a child wrongfully taken abroad. The article also looks at the jurisdiction of a requested court being able to refuse the enforcement the above-mentioned decision by reference to violation of its own constitutional principles or to the grave violation of the basic rights of the child. In the Zarraga case, in connection with the facts of the wrongful removal of a child, the CJEU came to face the issue of how to reconcile EU principles such as the principle of mutual trust with principles of procedure within the area of fundamental human rights, such as the child's right to be heard.
\end{abstract}

Keywords: principle of mutual trust, child's right to be heard, basic rights of the child, Zarraga case, wrongful removal of a child

\section{INTRODUCTION}

From the beginning, the mutual recognition and enforcement of cross-border judgments has been the fundamental basis for the establishment of the single European judicial area. In the areas of civil and commercial matters, the Brussels Convention of 1968 laid the foundations ${ }^{1}$ that were subsequently taken further by the Brussels I Regulation ${ }^{2}$ through further simplification of the recognition and enforcement (exequatur) conditions. In the area of family law, Brussels IIa was one of the first pieces of regulations ${ }^{3}$ that, in proceedings for the return of a child, made enforcement automatic through the abolishment of exequatur.

The precondition for the complete abolishment of exequatur is to be found in the fulfilment of the principle of mutual trust between member states. The principle of mutual trust as a milestone in judicial cooperation, completely pervades and defines the legislation through regulations. This is implied by the particular attention is given to its application during preparatory activities for each regulation.

* Associate professor, Pázmány Péter Catholic University, Faculty of Law and Political Sciences, Department of Private International Law. E-mail: raffai.katalin@jak.ppke.hu

1 Convention signed in Brussels on 27 September 1968 on jurisdiction and the enforcement of judgments in civil and commercial matters (as amended).

2 Council Regulation (EC) No 44/2001 of 22 December 2000 on jurisdiction and the recognition and enforcement of judgments in civil and commercial matters (OJ L 12, 16/01/2001, Hungarian special edition Chapter 19 Volume 4 42-64.).

3 Council Regulation (EC) No 2201/2003 of 27 November 2003 concerning jurisdiction and the recognition and enforcement of judgments in matrimonial matters and the matters of parental responsibility, repealing Regulation (EC) No 1347/2000 (HLL 388; Hungarian special edition Chapter 19 Volume 6 243.). 
The principle of mutual recognition, as one of the alternative solutions to the absence of the harmonisation of laws, ${ }^{4}$ initially played a role in the formation of the common market and became universally recognised following the decision delivered in the Cassis de Dijon case. The CJEU, in its subsequently developed case law, consistently applied this principle, also encouraging EU legislation.

The principle of mutual recognition also appears in several places in the founding treaties, with particular significance for the topic of this article in TFEU Article 67 paragraph (4) and Article 81 paragraph (2) point (a), which prescribes with respect to legislative proceedings the explicit implementation of the mutual recognition and enforcement of member states' decisions. This is augmented in point (f) by the objective of removing obstacles in order to achieve smooth civil proceedings, when necessary, by furthering the harmonisation of the rules of civil procedural law in member states.

It is essential, when discussing issues of procedural law, to examine the complete implementation of principles of procedural law that also have human rights connotations, such as the principle of a fair trial ${ }^{5}$ that forms the basis of systems of procedural law. Within this context, the child's right to be heard has special importance in cases involving the legal status of a child in a family.

This central topic for this article is a CJEU decision that allows for the study of the application of the principle of mutual trust and a child's right to be heard in the enforcement of a decision ordering the return of a child wrongfully taken abroad. This article also looks at the jurisdiction of a requested court being able to refuse the enforcement the abovementioned decision by reference to violation of its own constitutional principles or to the grave violation of the basic rights of the child.

\section{THE FACTS AND REFERENCE FOR A PRELIMINARY RULING $^{6}$}

In 2000, a daughter, Andrea was born to the married Joseba Andoni Aguirre Zarraga, a Spanish citizen and Simone Pelz, a German citizen. The family's habitual residence was in Spain. The spouses' relationship deteriorated in 2007, they subsequently separated and both parties applied for divorce as well as sole rights of custody of the child before the Spanish courts. The Bilbao Magistrate's court's decision of 12 May 2008 granted the father provisional rights of custody with the mother receiving access rights. The decision was based on the recommendations of an expert report, requested by the court from psychosocial services. The father, according to the report, was better able to provide for the maintenance of the child's family and social environment. As the mother had repeatedly stated that she intended to move to Germany with her new partner and the child, the court, in making the decision, held that granting the mother custody would be contrary to the recommendation of the report.

In June 2008, Simone Pelz moved to Germany, where she currently resides. The child spent the summer school holiday, August 2008, with her mother and did not return to Spain to her father at the end of the holiday. On 5 October 2008, at the father's request, the Bilbao

${ }^{4}$ See further Blutmann (2010) 248-250.; Dienes-Oehm, Erdős, Király, Martonyi, Somssich, Szabados (2010) 60-65.

5 Kramer (2011) 202-230.

6 Ruling made on 22 December 2010 in the proceedings of Case C-491/10 PPU Joseba Andoni Aguirre Zarraga v. Simone Pelz, ECR 2010 I-14247. 
court issued a temporary injunction forbidding the child from leaving the territory of Spain accompanied by her mother of any maternal relative and suspended the mother's access rights until the final decision.

In June 2009, the proceedings for custody continued before the same court. The court held that commissioning a new expert report was necessary, as well as a hearing with the daughter, for which it set deadlines. On the specified deadline, neither Andrea, nor her mother presented themselves before the Bilbao Magistrate's court. The court did not grant Simone Pelz's request for permission for herself and her daughter to freely leave Spain after the hearing. It also refused the mother's application for the child to be heard via video link.

In its ruling of 16 December 2009, the Juzgado de Primera Instancia e Instrucción $n$. 5 de Bilbao granted divorce and awarded the father sole rights of custody. The mother appealed against the ruling, objecting to, among other things, the lack of a hearing for the child. The Audiencia Provincial de Bizkaya (Biscay Provincial Court) rejected this appeal in its ruling of 21 April 2010 with the justification that according to procedural rules, taking of evidence in the appeal process is only possible in circumstances specified in law that do not include voluntary failures by parties correctly summoned to a hearing of first instance.

The father also initiated proceedings in German courts in parallel with the Spanish courts proceedings. He started the first set of proceedings on the basis of the Hague Convention on the Civil Aspects of International Child Abduction (Hague Abduction Convention) with the aim of returning his daughter to Spain. The Amstgericht Celle (Regional Court of Celle) granted his application and the mother appealed the decision. The Oberlandesgericht Celle (Regional Appeals Court of Celle) granted the appeal and heard the child, who was expressly against being returned to her father. Following the hearing, the expert witness came to the conclusion that Andrea's opinion should be taken into account based on her age and maturity. In view of all the above reasons, based on Article 12 paragraph 2 of the Hague Convention, the Celle Court of Appeal rejected J. A. Aguirre Zarraga's application for return of the child. ${ }^{7}$

The second set of proceedings before German courts was initiated by the father with reference to a certificate issued on 5 February 2010 according to Article 42 of Brussels IIa on the basis of the judgment of the Juzgado de Primera Instancia e Instrucción $n .5$ de Bilbao granting divorce and awarding custody, based on which the judgment ordering the return is enforceable.

Simone Pelz objected to the enforcement of the certified judgment and applied for refusal of recognition for the decision. The Amstgericht Celle stated in its decision on 28 April 2010 that the judgment cannot be recognised and cannot be enforced because the Spanish court had not heard the child before delivering the judgment. The father lodged an appeal against this decision with the Oberlandesgericht Celle, applying for a repeal of the decision, rejection of the mother's application, as well as an official order enforcing the decision returning the child to the father.

Although the certificate issued on the basis of Article 42 of Brussels IIa may not be overruled by the enforcing court with reference to Article 21 of the regulation and this was also accepted by Oberlandesgericht Celle. Nevertheless, it held that enforcement could be questioned in case of a grave violation of fundamental rights. The Spanish court had not heard the child, who thus had not been able to relate which parent she would like to live with and her position could not have been taken into account by the Spanish court for its 
custody decision. According to the German court, the efforts of the Spanish court to hear the child had been insufficient, especially with respect to Article 24 paragraph (1) of the Charter of Fundamental Rights, which states that children's views must be taken into consideration on matters which concern them in accordance with their age and maturity.

In addition, the Oberlandesgericht Celle also raised doubts on whether an enforcing state could be bound by the enforcement of certificate that is obviously wrong, since said certificate, issued by the Juzgado de Primera Instancia e Instrucción $n$. 5 de Bilbao on 5 February 2010 contains an evidently false declaration as it states that it had heard the child, which never happened. Overall, it held that the case raised the possibility of a grave breach of fundamental rights, therefore it stayed the proceedings and referred the following questions to the CJEU for a preliminary ruling.

"(1) Where the judgment to be enforced issued in the Member State of origin contains a serious infringement of fundamental rights, does the court of the Member State of enforcement exceptionally itself enjoy a power of review, pursuant to an interpretation of Article 42 of [Regulation No 2201/2003] in conformity with the Charter of Fundamental Rights?

(2) Is the court of the Member State of enforcement obliged to enforce the judgment of the court of the Member State of origin notwithstanding the fact that, according to the casefile, the certificate issued by the court of the Member State of origin under Article 42 of [Regulation No 2201/2003] contains a declaration which is manifestly inaccurate?"

\section{LEGAL CONTEXT RELEVANT TO THE CASE}

The CJEU had to consider three sources of law in its response to questions posed by the national court: Brussels IIa Article 42 paragraph (2) point (a); Article 24 of the Charter of Fundamental Rights of the European Union; and the Article 13 paragraph (2) of the Hague Convention on the Civil Aspects of International Child Abduction, dated 25 October 1980.

In civil cases involving cross-border family law issues, the basis of the framework of judicial cooperation is, without any doubt, Brussels IIa. To interpret the relevant parts of the regulation, the Practice Guide for the application of the Brussels IIa Regulation was used, hereinafter the Practice Guide. ${ }^{8}$

The objective of the regulation is the extension of judicial cooperation in civil matters to certain areas of family law, more specifically the definition of jurisdiction for proceedings on divorce and spouses' custody rights for common children as well as recognition and enforcement of judgments. The starting premise is the creation of a uniform EU legal area organised around the principle of mutual recognition and enforcement of court judgments. ${ }^{9}$ It subordinates to this principle the proceedings for children being wrongfully moved abroad and the issue of court decisions, for which it foresees direct and automatic enforcement. This general rule sets the framework for the regulation of children being abducted from their country of habitual residence.

8 Practice Guide for the application of the Brussels IIa Regulation. www.europa.eu.int/ civiljustice (downloaded: 21/05/2014).

9 Council Regulation (EC) No 2201/2003 of 27 November 2003 concerning jurisdiction and the recognition and enforcement of judgments in matrimonial matters and the matters of parental responsibility, repealing Regulation (EC) No 1347/2000, Preamble paragraphs (1) and (2). 
According to paragraph (12) of the preamble, jurisdiction for parental responsibility is determined by taking into account the basic interests of the child, primarily using the connecting factor of the child's place of habitual residence. However, the regulation does not define the concept of habitual residence - it must be defined by the judge assigned to each case based on the facts. The Practice Guide emphasises that, nevertheless, the concept of habitual residence should be interpreted not based on peculiarities of national law but autonomously according to EU law. In the case of a child moving from one member state to another, attaining the new habitual residence means the lose of the previous one. However this change does not have an effect of jurisdiction. The court rules on jurisdiction when a request is filed and if it determines that it has jurisdiction, it is retained even if the child gains habitual residence in another member state. Therefore, a change in place of habitual residence does not give rise to a change in jurisdiction. There are also exceptions alongside the general rule: Jurisdiction may exceptionally be moved to the state where the child has moved (Article 15) when required by the interests of the child; jurisdiction may also be wielded by a state where the child does not have a habitual residence in exceptional cases. However, if the child's habitual residence changes as a result of wrongful removal of retention then there are very strict conditions when the jurisdiction may change. The primary objective of the regulation is to prevent the wrongful removal of children and if this should happen, then provide for their return to the original state. In this, Brussels IIa Regulation effectively supplements The Hague Convention, which has been ratified by every member state and which, as in international source of law, plays a central role in proceedings for the wrongful removal or retention of children. The regulation declares its precedence over the convention in matters under its jurisdiction in relationships between member states.

The regulation addresses wrongful removal and retention in line with the following main rules: Jurisdiction remains with the court based on the place of the original action; the requested member state must guarantee the immediate return of the child; authorities of the member state of the original action and the requested member state must cooperate in order to resolve the wrongful removal as soon as possible. The most important rule is that the judicial decision ordering the return of the child must be enforced immediately and directly, without an exequatur by the court of the requested state where the child is being wrongfully retained. The main principle is that the child should always be returned provided they are protected in the member state of the original action.

Specific, well justified cases can result in the refusal of the return of a child. ${ }^{10}$ The regulation interprets these exceptions by narrowly interpreting and reducing to the minimum the provisions of the Hague Convention Article 13 point (b) (Brussels IIa Regulation Article 11 paragraph 4). According to the Hague Convention Article 13 point (b), the court is not bound to order the return of the child if there is a grave risk that their return would expose the child to physical or psychological harm or otherwise place the child in an intolerable situation. The regulation further restricts this freedom for refusal by extending the obligation to order the return in cases where, although there may be a risk of harm, it can also be shown that measures are in place in the member state of the original action to guarantee protection of the child following their return. The court must always evaluate this in the context of the specific situation i.e., whether such concrete protective measures have been taken in the state of the original action.

10 Preamble paragraph (17). 
The regulation emphasises the importance of the principle of mutual trust and this is also supported by the provision requiring that the legal basis for refusing recognition should be kept to the necessary minimum. ${ }^{11}$

These procedures are supplemented by a provision requiring that decisions on return that have been certified in the member state of the original action be recognised and enforced in every member state, without any separate procedure. No appeal shall filed against the certificate. The certificate may only be amended is there is substantial error i.e. if the certificate does not adequately reflect the judgment. ${ }^{12}$

The regulation recognises and guarantees the fundamental rights of the child, particularly Article 24 of the Charter of Fundamental Rights. ${ }^{13}$ Hearing the child plays an important role in the proceedings and the Brussels IIa Regulation, in concert with the Charter of Fundamental Rights emphasises this principle of procedural law. A fundamental difference is that in the regulation, Article 11 paragraphs (2) and (5), there is no general obligation for hearing the child and the court may dispense with this if deemed inappropriate due to the age or level of maturity of the child. The hearing may also take place in another member state, according to the provisions of the regulation on taking evidence in civil and commercial matters. ${ }^{14}$ Speed is the most important principle with respect to hearing the child. The court must apply the fastest proceedings available in international law and take a decision within six months, Article 11 paragraph (3), and thus the hearing must be conducted in the fastest and most effective manner possible. In this respect, courts of member states are bound to work together and during taking of evidence, the court of one member state may request that a court of another member state conduct the taking of evidence but per Article 10 paragraph (4) of the regulation, video and telephone links may also be used.

Article 13 paragraph (2) of the Hague Convention is strongly worded in that the court is not bound to order the return of the child if they are in opposition to the return and has reached a certain age and level of maturity.

The interpretation of the child's right to be heard is also a central topic in Advocate General Bot's statement. ${ }^{15}$ His opinion, with respect to the substance of the child's fundamental right to be heard, is that Article 42 should be interpreted autonomously in the context of the regulation's taxonomic relationships. It is not a prerequisite that it be in accord with the constitution of the state where the child was wrongfully taken or retained for the child to receive the opportunity to be heard. This provision stems from the regulation text which, in this context, contains no reference to the jurisdiction of member states but is also underpinned by the imperative to implement the principle of effective and fast return. ${ }^{16}$ The regulation, when compared to the convention, is also more permissive in enabling the resolution of stalemate situations when the court of the member state of the original action and the requested state interpret this right differently with view to the fundamental rights provided by their respective legal systems. ${ }^{17}$

11 Preamble paragraph (21).

12 Preamble paragraphs (23) and (24).

13 Preamble paragraph (33).

14 Council Regulation (EC) No 1206/2001 of 28 May 2001 on cooperation between the courts of the Member States in the taking of evidence in civil or commercial matters (OJ L 174, 27/06/2001), Preamble points (19) and (20).

15 Advocate General Yves Bot's statement. Date of presentation 7 December 2010.

16 Advocate General Bot's motion points 73-75.

17 Advocate General Bot's motion point 76. 
However, the regulation does not mandate the hearing of the child, it encompasses the child's right to be heard but requires that attention be paid so that the child is not placed in a situation that would cause the child harm, in that they would be solely responsible for deciding whether to return. For this reason, the conditions for attaining the child's statement must be linked to age and level of maturity. For the case in question, the Spanish court was reasonable in ruling that a video link hearing would be inappropriate for a child as young as Andrea.

According to Article 42 paragraph (2) point (a), the regulation does not require that the court of the member state of the original action conduct the hearing of the child. It merely requires that the child receive the opportunity to be heard. Therefore this condition is satisfied if the child has been heard by the judicial authorities of another member state, as indeed happened, when the institutions of the state of enforcement heard the child. In accordance with this, the child's right to be heard was not violated.

Article 42 of the regulation, the interpretation of which by the CJEU was requested by the court of Celle, in conjunction with the framework outlined in the preamble requires that the judgment ordering return by the court of the member state of the original action be enforced provided that this judgment has been certified by the issuing court. The certificate is issued officially by the court using the applicable form. The certified judgment must be recognised and enforced in another member state without any process of exequatur or dispensation to refuse recognition.

Paragraph (2) point (a) precisely defines the conditions for issuing the certificate, which can continue when the child has been heard in the proceedings except if the court held that the hearing would be inappropriate due to the child's age or level of maturity. ${ }^{18}$

The Hague Abduction Convention has been ratified by every member state, and as a primary source of international law in proceedings for children's wrongful removal, in an EU context supplements the Brussels IIa Regulation, the application of which has precedence in relation to member states.

The objective of the Convention is that signatory states respect children's rights of custody with respect to each other, as well as establish a unified international legislative framework that ensures the fastest possible return of a child wrongfully removed to any signatory state. Therefore, if a child has been wrongfully removed, the return of the child to their habitual residence must be ordered. Such almost automatic return orders may exceptionally be limited by taking into account the child's interest and circumstances. Article 13 of the Convention defines the cases when the authorities of a requested state are not bound to order the return of a child. A full listing is not included but the second

18 Brussels IIa Regulation Article 42 ,Return of the child.

(1) The return of a child referred to in Article 40(1)(b) entailed by an enforceable judgment given in a Member State shall be recognised and enforceable in another Member State without the need for a declaration of enforceability and without any possibility of opposing its recognition if the judgment has been certified in the Member State of origin in accordance with paragraph (2).

(2) The judge of origin who delivered the judgment referred to in Article 40(1)(b) shall issue the certificate referred to in paragraph (1) only if:

a) the child was given an opportunity to be heard, unless a hearing was considered inappropriate having regard to his or her age or degree of maturity;

b) the parties were given an opportunity to be heard; and

c) the court has taken into account in issuing its judgment the reasons for and evidence underlying the order issued pursuant to Article 13 of the 1980 Hague Convention. 
paragraph, relevant to the Zarraga case will be exclusively discussed. It states that it is not obligatory to order return of the child who is sufficiently mature, whose opinions may be taken into account and who opposes the return. This rule implements the consideration of the best interests of the child. ${ }^{19}$

Article 20 of The Hague Convention supplements Article 13 by stating that ordering the return of the child may be refused if this would not be permitted by the fundamental principles of the requested State relating to the protection of human rights and fundamental freedoms. ${ }^{20}$

The Charter of Fundamental Rights is equally binding as the Treaties based on Article 6 TEU. Article 24 paragraphs (1)-(3) of the Charter of Fundamental Rights, ${ }^{21}$ which deal with the rights of the child, derived primarily from protection and care guaranteeing the welfare of the child. It declares the child's freedom of expression and requires that children's views must be taken into consideration on matters which concern them in accordance with their age and maturity. In actions relating to children, the child's best interests must be the primary consideration. Every child should have the right to maintain on a regular basis a personal relationship and direct contact with both parents, unless that is contrary to their interests.

\section{THE JUDGMENT OF THE CJEU}

The CJEU took the view that wrongful removal or retention of the child in contravention of a court decision in another member state gravely violates the interests of the child and therefore the regulation mandates measures to ensure that the child be returned as quickly as possible to their habitual residence. To this end, it established a framework where in case of a difference in opinion between the court of the child's place of habitual residence and that of the wrongful place of residence, it is the former that has sole jurisdiction over the issue of the child's return. It also provides that courts utilise the fastest possible procedures available to them for under international law. This is also the aim of the specified deadline; courts must publish a judgment within at most six months of the filing of an application in the absence of exceptional circumstances, hindering the proceedings.

19 The Hague Convention Article 13 ,The judicial or administrative authority may also refuse to order the return of the child if it finds that the child objects to being returned and has attained an age and degree of maturity at which it is appropriate to take account of its views.

In considering the circumstances referred to in this Article, the judicial and administrative authorites shall take into account the information relating to the social background of the child provided by the Central Authority or other competent authority of the child's habitual residence."

20 The Hague Convention Article 20 , The return of the child under the provision of Article 12 may be refused if this would not be permitted by the fundamental principles of the requested State relating to the protection of human rights and fundamental freedoms."

${ }^{21}$ Charter of Fundamental Rights Article 24 ,The rights of the child

(1) Children shall have the right to such protection and care as is necessary for their well-being. They may express their views freely. Such views shall be taken into consideration on matters which concern them in accordance with their age and maturity.

(2) In all actions relating to children, whether taken by public authorities or private institutions, the child's best interests must be a primary consideration.

(3) Every child shall have the right to maintain on a regular basis a personal relationship and direct contact with both his or her parents, unless that is contrary to his or her interests." 
The regulation, as well for speed, reinforces the principle of mutual trust, according to which the legal basis for refusing recognition of judgments brought in member states should be kept to the necessary minimum and enforcement of the decision ordering the return of the child be performed in the member state where the child resides, without the requirement for separate proceedings for said decision to be recognised and enforced in that member state.

Specifically to ensure speedy enforcement of decisions, the Articles 40-45 of the regulation prescribes a special framework that allows for these decisions to be enforceable in the member state where their legal effect is needed. Thus, a decision ordering the return of a child, published by a competent court, provided it is final and has been certified according to the regulation in the member state of the original action, must automatically be enforced without dispensation to refuse recognition of the decision. Therefore the certificate issued by the court of the member state of origin may only be amended according to the rules of the law of the member state of origin and doubts about the authenticity of the certificate may only be referred to under the rules of the law of the member state of origin. ${ }^{22}$

To aid of the quick return of children is the requirement that questions about the legality of the decision ordering return, especially whether the necessary conditions have been met for a court with jurisdiction to publish such a decision, must be brought before the courts of the member state of origin, according to the laws of that member state. According to Article 42 paragraph (2), in no way does the regulation authorise the court of the member state of enforcement to carry out a review of the issuance of the certificate. ${ }^{23}$ All this rests on the premise that member state courts meet their obligations under Brussels IIa Regulation in their own jurisdictions in accordance with the Charter of Fundamental Rights. The regulation therefore cannot be contrary to the Charter of Fundamental Rights; the provisions of Article 42, which implement the child's right to be heard, must be interpreted according to Article 24 of the Charter. ${ }^{24}$ Concurrently, the relevant articles of the Charter and regulation imply that hearing the child is an option but not an obligation. In matters concerning children, they are entitled to express their views freely, but such views must only be taken into consideration by courts "in accordance with their age and maturity". In the context of this article, the overriding interests of the child must be taken into consideration and these interests could, in some cases, justify dispensing with the hearing of the child. Hearings are thus not a complete obligation but must be weighed up in each case based on the requirements of the overriding interests of the child. The court of the member state of origin has a certain margin of discretion with respect to hearing the child, and if it opts for a hearing, then it must, whilst keeping in mind the overriding interests of the child, utilise all instruments granted to it by its national laws, as well as the tools of cross-border judicial cooperation, and reach its decision on that basis. Finally, the legality of the decision may be reviewed exclusively by the courts of the member state of origin because of the basis in the principle of mutual trust between member states, meaning that their national rules are able to provide equivalent and effective protections in view of the fundamental rights granted at EU level, and especially by the Charter of Fundamental Rights. All of this implies that only the state court of origin may verify whether, the

22 Zarraga judgment sections $45-48$.

23 Zarraga judgment sections $50-52$.

24 Zarraga judgment sections 59-60. 
certificate issued on the basis of the decision involves the violation of the child's right to be heard..$^{25}$

Based on these reasoning, the CJEU's response to the questions was that the competent court of the member state of enforcement may not refuse enforcement of the certified decision ordering the return of the child wrongfully retained due to possible infringement, since this falls under the sole jurisdiction of the court of the member state of origin. ${ }^{26}$

\section{BRIEF SUMMARY}

In the Zarraga case, in connection with the facts of the wrongful removal of a child, the CJEU came to face the issue of how to reconcile EU principles such as the principle of mutual trust with principles of procedure within the area of fundamental human rights, such as the child's right to be heard.

It is the principle of mutual trust that enables the creation of a uniform judicial area within the European legal environment and allows for decisions to effectively cross borders. A prerequisite for this is for member states' courts be able to effectively guarantee equivalent fundamental rights, especially those provided by the Charter of Fundamental Rights. The objective of mutual trust and recognition is the establishment of a uniform system within the European judicial area that most closely approximates the situation when factual elements similar to these arise in family law within a single member state. However, this prerequisite was not satisfied in the Zarraga case, as can be seen in the criticisms levelled at the decision. ${ }^{27}$

It seems, from the facts, that member states' courts sometimes fulfil their obligation to cooperate in questionable ways. The Spanish court, when the child and mother failed to show up on the deadline rejected the application for a hearing of the child and mother over video link, although this option was open to it under available EU legal instruments and its obligation to cooperate, and thereby could have allowed for the child to effect her right to free expression. Unfortunately, the CJEU, in this ruling, did not consider this issue with the emphasis it merited. It can be argued that it is an issue falling under the discretion of the Spanish court, which aimed to resolve the dispute in the best interests of the child whilst complying with the requirement for a speedy conclusion. The Spanish court had access to the German expert report, which had determined that the child wished to remain with her mother but the Spanish court, using its discretion, did not take this into account. This point gives rise to another question - how would the Spanish court have ruled with respect to the child's level of maturity if this opinion was duly considered? Would it have taken into consideration the opinion of the nine-year-old child? The CJEU has failed to provide an interpretation of Article 42 paragraph (2) sub-paragraph 1 point (a). Although it is unreasonable to expect the determination of a specific age threshold, the CJEU could have, at least, outlined a few relevant factors.

The decision has also exposed a deficiency; there is absolutely no consistency in the necessity of a child's right to be heard between Brussels IIa Regulation and the framework of the Hague Convention. The regulation interprets its scope much more narrowly and

25 Zarraga judgment sections 63-66.

${ }^{26}$ Zarraga judgment section 76 .

27 Holliday (2012) 397-412; Kramberger Skerl (2011) 461-490. 
places the decision at the discretion of the court. While the Convention treats the child's right to be heard as an absolute right and one of the manifestations of the fairness of proceedings, like the right to be heard, it is decoupled in the context of EU law and CJEU case law. The CJEU, in its decisions interpreting the Brussels Convention has repeatedly emphasised that ignoring the right to be heard infringes fundamental human rights and as such it is contrary to the public order of an executing state. ${ }^{28}$ Yet the framework of Brussels IIa Regulation, by abolishing exequatur, has removed this option and concerns stemming from the disappearance of this instrument are becoming reality. ${ }^{29}$

Extremely narrow interpretation of the regulation, the total disempowering of enforcing courts as well as ignoring their position also risks breaking the trust between member states. This is evident by the case's aftermath. As of Spring $2014^{30}$, despite of the CJEU judgment published years earlier, the Oberlandesgericht Celle still has not enforced the Spanish order to return. It first awaited the evaluation of the mother's application for alteration in accordance with Article 11 paragraph (8) of the regulation. After the Bilbao court rejected her appeal against its decision, the mother filed a constitutional complaint, which was similarly rejected by the Spanish Constitutional Court in January 2013. The High Court of Celle attempted to achieve reconciliation between the parties resulting in the father and daughter meeting personally on two occasions. After the parties failed to reach an agreement, the German court ordered forced execution of the decision. Since the executor, with the father present, failed to convince the daughter to leave for Spain with her father, the court of appeal made a ruling that German law does not provide further legal instruments that could be used to force successful enforcement. The mother could not be fined, because she cooperated fully with the authorities and made a good effort to convince her daughter to leave. Force could not be used against the daughter, who had turned thirteen-and-a-half, because German law deemed her sufficiently mature for her protest against leaving with her father to have to be taken into consideration as part of the enforcement proceedings. The European Commission is likely to initiate proceedings against Germany.

\section{LITERATURE}

Blutmann, L., The Law of the European Union in Practice (HVG-Orac 2010).

Dienes-Oehm, E., Erdős, I., Király, M., Martonyi, J., Somssich, R., Szabados, T., Economic Law of the European Union I (ELTE Eötvös Press 2010).

Dutta, A., Schulz, A., 'First Cornerstones of the Rules on Cross-Border Child Cases: the Jurisprudence of the Court of Justice of the European Union on the Brussels IIa Regulation from C to Health Service Executive' (2014) 1 Journal of Private International Law 28-29.

Holliday, J., 'Case Comment: Aguirre Zarraga v Simone Pelz; Jan-Jaap Kuipers: The (Non) Application of the Charter of Fundamental Rights for Return of a Child' (2012) 4 European Human Rights Law Review 397-412.

Kramberger Skerl, J., 'European Public Policy (with an Emphasis on Exequatur Proceedings)' (2011) 3 Journal of Private International Law 461-490.

Kramer, X. E., 'Cross-border Enforcement in the EU: Mutual Trust versus Fair Trial? Towards Principles of European Procedure' (2011) 2 Journal of Procedure Law 202-230.

Raffai, K., 'The (planned) total abolishment of the exequatur and its ramifications for public policy' (2012) 9 Magyar Jog 547-554.

28 Case C-7/98 Krombach v. Bamberski ECR 2000 I-1935; case C-394/07 Gambazzi ECR 2009 I-02563.

29 Raffai (2012) 547-554.

30 See Dutta, Schulz (2014) 28-29. 